\title{
RECONSTRUCTING THE HERO: REPRESENTATION OF LOYALTY IN LATE ANGLO-SAXON LITERATURE
}

\author{
Şafak NEDİCEYUVA ${ }^{1}$
}

\begin{abstract}
Danish attacks on the British Isles in the $9^{\text {th }}$ century had considerable political consequences for the seven Anglo-Saxon kingdoms reigning independently at the time. 'The Great Heathen Army', as the Anglo-Saxon called it, began a series of invasions in Britain and their advance was unstoppable until all Anglo-Saxon kingdoms but Wessex were conquered. Emerging as the rulers of only surviving Anglo-Saxon kingdom, Alfred and the subsequent monarchs of Wessex began a slow process of unifying the subjugated Anglo-Saxons under their banner and they desired to be acknowledged as the kings of England, rather than Wessex. By adapting traditional heroic values to contemporary political needs, literary works of this period similarly attempt to channel former tribal loyalties towards the monarch and propagandize absolute devotion to the survival and construction of 'England'. This article discusses the ideological role literature played in late Anglo-Saxon era during the formation of England.
\end{abstract} organization.

Keywords: Anglo-Saxon, Viking, hero, heroic code, military

\section{KAHRAMANIN YENIDEN KURGULANIŞI: GEÇ DÖNEM ANGLOSAKSON EDEBIYATI'NDA SADAKATIN TEMSİLİ}

\section{ÖZ}

Dokuzuncu yüzyılda Britanya Adaları'na yapılan Viking saldırıları burada hüküm süren yedi bağımsız Anglosakson krallığı için önemli siyasi sonuçlar doğurmuştur. Anglosaksonların 'Büyük Dinsiz Ordu' adını verdikleri ordu Britanya'yı istila etmeye başlamış ve Wessex Krallığı dışında tüm diğer krallıklar yıkılana kadar durdurulamamıștır. Alfred ve ondan sonra tahta çıkan Wessex kralları ayakta kalan tek Anglosakson krallığının hükümdarları olarak Viking buyruğu altındaki Anglosaksonları kendi bayrakları altında bir araya getirmeyi ve Wessex değil İngiltere krallı̆̆ olarak tanınmayı arzulamışlardır. Dönemin edebi metinleri de gelenekselleşmiş kahramanlık değerlerini güncel siyasi ihtiyaçlara uyumlu hale getirmek suretiyle, alışılmış kabile içi sadakat ve bağlılıkları krala yönlendirmeye ve İngiltere'nin kuruluşu ve kurtuluşunu teşvik etmeye çalışmaktadır. Bu makale Ingiltere'nin kuruluşu aşamasında edebiyatın üstlendiği ideolojik rolü tartışmaktadır.

Anahtar Kelimeler: Anglo-Saxon, Viking, hero, heroic code, military organization.

1Yrd. Doç. Dr., İstanbul Yeni Yüzyıl Üniversitesi, Fen-Edebiyat Fakültesi, İngiliz Dili ve Edebiyatı Bölümü, safak.nediceyuva@yeniyuzyil.edu.tr. 


\section{Introduction}

Study of the Anglo-Saxon literature covers the lengthy period between the mid-fifth and early twelfth centuries. Anglo-Saxon society went through considerable political changes in this period, and the effects of these political changes on Anglo-Saxon culture are noteworthy. In the $9^{\text {th }}$ century, the Danish invasion of England started, but the subsequent victories of the Anglo-Saxon kingdom of Wessex lead to the unification of the petty Anglo-Saxon kingdoms into a single English crown. This transition from the Anglo-Saxon Heptarchy to the Kingdom of England had significant cultural and ideological changes in the Anglo-Saxon society. Anglo-Saxon Heptarchy consisted of the seven kingdoms of Northumbria, Mercia, East Anglia, Essex, Kent, Sussex and Wessex, which existed in England until they were eventually conquered by the Danish. The Kingdom of Wessex was the only survivor of the Danish attacks, which later evolved into the Kingdom of England. The foundation of the Kingdom of England also paved the way to the formation of an English identity among the Anglo-Saxons. In this article, I explore how late Anglo-Saxon rulers tried to foster this sense of Englishness among their subjects through their use of literature.

Alfred, who reigned as the King of Wessex between 871 and 899, was one of the major figures during the $9^{\text {th }}$ century Anglo-Saxon - Danish conflict. Besides his military victories against the Danish, he is also recognized for the many cultural reforms he initiated in order to remedy the educational decline that these attacks caused in England. Douglas John Vivian Fisher claims in his "The Anglo-Saxon Age" that

Alfred was the first king in England who identified himself with the 'English' regardless of their local affiliations. His predecessors, whether kings of Northumbria, Mercia, or Wessex, had been rulers who waged war on neighboring kingdoms with the intention of reducing them to subjection and imposing tribute upon them" (Fisher, 1973: 225)

Therefore, it is safe to claim that although they shared a common Anglo-Saxon culture, the seven Anglo-Saxon kingdoms were separate and rival political entities until the Danish invasion. As Alfred was the leader of the only Anglo-Saxon kingdom that survived the Danish invasion, his reforms were intended to influence the Anglo-Saxon society as a whole. However, in order to do so, Alfred had to mold Wessex into the Kingdom of England, and legitimatize his rule as the king of all Anglo-Saxons.

2 | Celal Bayar Üniversitesi Sosyal Bilimler Dergisi - Cilt: 13, Sayı: 3, Eylül 2015 
Thus, with the power vacuum that the Danish invasions and the subsequent victories of Wessex created, Anglo-Saxon society saw a shift from the earlier, tribal social organization to a more organized and centralized government. Similarly, as discussed in this article, Anglo-Saxon heroic and military values gradually began to highlight the rights of kings over their retainers. Since there was only one Anglo-Saxon king who ruled in England, there was no chance to switch allegiances for members of the Anglo-Saxon military, and this stricter version of the Anglo-Saxon heroic code played a crucial part in King Alfred's and his successors' efforts to foster a common English identity among the subjects of the recently defeated AngloSaxon Heptarchy.

\section{Defining the Anglo-Saxon Heroic Code}

Unwritten and customary rules of conduct between superiors and subordinates determined the rights and responsibilities of the members of the Anglo-Saxon military. Referred collectively as the Anglo-Saxon heroic code, these abstract rules existed among other Germanic tribes as well, and as they began their settlement in Britain in the $5^{\text {th }}$ century, various Anglo-Saxon tribes brought these military values with them from their continental homelands. Several historians and literary critics have attempted to define the key values of the Anglo-Saxon heroic code. All critics agree that Anglo-Saxon heroic code demands loyalty to two major bodies: the king and the kin. In his The Anglo-Saxon Warrior Ethics, John M. Hill attempts to summarize three major principles of Anglo-Saxon heroic code:

(i) mutual loyalty between the warlord and the retainer, through exchange of gifts for military services, (ii) revenge obligation regarding injury or death, on behalf of kinsmen and lord; and iii) public display of battle courage, especially if victory seems impossible (Hill, 2000: 1)

In her "Heroic Values and Christian Ethics", Katherine O'Brien O'Keeffee reminds other points:

Retainers must accompany their lord in the event that he is exiled; they must participate in warfare as a payment for feasts and treasures distributed; and they lose land and rights as a price for cowardice" (O'Keeffee, 2002: 109)

Likewise, in "Kinship in Anglo-Saxon Society", Lorraine Lancaster writes: "support in battle must be considered an important expectation of kinship, and in some cases this would be reinforced by the fact that a kinsman might also be a man's lord" (Lancaster, 1958: 369). 
As previously stated, when the Anglo-Saxon tribes invaded England in the $5^{\text {th }}$ century, they brought with them the Germanic heroic code. The heroic poems and other texts analyzed in this article reveal that the Germanic heroic code was still present in the AngloSaxon society even after their arrival to Britain and conversion to Christianity. For instance, "Beowulf" and "Battle of Maldon" depict life as a continuous struggle, and it is meaningless unless it is put into good use. The intertwined nature of heroic and Christian poetry is a defining feature of Anglo-Literature. In this respect, the pre-Christian belief of 'Wyrd' is especially important. Wyrd literally means 'what happens', and refers to personal destiny. The warrior is bound to his wyrd, and wyrd decides the outcome of any struggle that the warrior faces. In Germanic paganism, three women, collectively called 'Norns', continuously weave the fates of everyone, including the gods. The wyrd is undisclosed even to gods, and is inescapable. Although wyrd is a pagan concept, it has retained its existence in Anglo-Saxon poetry as seen in "Beowulf": "Often, for undaunted courage / fate spares the man it has not already marked" (Beowulf, 2000: 39).

Another essential part of the Anglo-Saxon heroic code is 'lof'. Warriors must look for ways to attain 'lof', that is, making a name and gaining immortality through bravery in battle. 'Wyrd' and 'lof' carry both pagan and Christian overtones. Thus, when the "Beowulf" poet says: "So must a man do when he thinks to win enduring fame in battle; he will show no concern for his life" (ibid. 107), he implies that former Anglo-Saxon beliefs like 'lof' does not conflict with the belief in a Christian afterlife. Belief in 'lof' led a warrior to show reckless bravery in the field of battle. Since 'lof' assured immortality to men, it was best to be courageous and fierce, as one could act cowardly and still die.

This kind of eagerness for bravery and recklessness entails another aspect of Anglo-Saxon heroic code: loyalty until death. The Germanic heroic code necessitates revenge obligation on the warrior. That is to say, if the warrior's lord were killed, it was the warrior's duty to avenge him. In return for such a loyalty, the lord had to provide shelter and deal wealth to his followers. The "Beowulf" poet writes:

And a young prince must be prudent like that, giving freely while his father lives so that afterward in age when fighting starts steadfast companions will stand by him and hold the line. Behavior that's admired is the path to power among people everywhere (ibid. 3,5)

4 | Celal Bayar Üniversitesi Sosyal Bilimler Dergisi - Cilt: 13, Sayı: 3, Eylül 2015 
Thus, in order to attract the best warriors, the king had to be brave and skillful just as his warriors. The fact that 'wyrd' and 'lof' can still be found in Christian Anglo-Saxon writings highlights the fusion of early and late understanding of the heroic code during Anglo-Saxon Era.

As discussed before, the core of the early Anglo-Saxon society was the war-band, which consisted of the warriors and their leader. As the leader displayed courage and won victories he acquired trophies to divide among his followers. This would in return, bring more followers to him and make him even stronger. Finally, as he grew in power, he would become a king and attract even more followers. One can see in the following description of Hrothgar, how the Anglo-Saxon society positioned itself around a successful chieftain. A group of warriors and their leader can turn into a "mighty army", as the leader grows a reputation both for success in war and for generosity:

The fortunes of war favored Hrothgar.

Friends and kinsmen flocked to his ranks, young followers, a force that grew

to be a mighty army. So his mind turned

to hall-building: he handed down orders

for men to work on a great mead-hall

meant to be a wonder of the world forever;

it would be his throne-room and there he would

dispense his God-given goods to young and old (ibid. 7)

As seen in these lines, as Hrothgar's power grows, he decides to construct a mead-hall, which is a display of power, and an extension of his growing sphere of influence. Thus, as much as loyalty between lord and retainer is a primary feature of the heroic code, it is also equally dependent on the lord's generosity.

Summarizing these discussions, one can see that the AngloSaxon heroic code has two main principles: firstly, trust and loyalty between the lord and his followers; secondly, having strong bonds with one's extended family. However, I argue that late Anglo-Saxon literature tends to present a one-sided version of the heroic code and emphasizes the duties of retainers, while rarely mentioning the responsibilities of kings such as gift-giving or generosity. Considering that the above mentioned principles of the heroic code were part of customs, and never written down as official directives by the AngloSaxons, the best way to see these principles is through analysis of literature. Literature gives one an insider's view about a society. Especially if a society is historically remote to the researcher, excluding disciplines like archaeology, literature is one of the best 
methods to study its cultural values. In this respect, one way to reach the early cultural heritage of English society is to study the literature of the Anglo-Saxon period.

The core argument of this article is that while the duties of the warriors and the responsibilities of the kings are equally important in earlier Anglo-Saxon works like "Beowulf"; the more recent Anglo-Saxon works "The Battle of Maldon", Old English translation of "Exodus", and Anglo-Saxon Chronicle constantly highlight the duties of the warrior and rarely mention kingly responsibilities. What is inferred from this observation is that in order for such a change in the depiction of the heroic code to occur in Anglo-Saxon literature, the political power structure must have changed in the Anglo-Saxon society as well. What is proposed in this article is that the Anglo-Saxon heroic code gradually evolved from an agreement between the warrior and the king, which protected both parties almost equally, into a restrictive ideological tool imposed only on the warriors.

\section{III. "Beowulf"}

A scene through the end of "Beowulf" can be considered an example for the significance the Anglo-Saxon society attributed to the heroic code, as well as the consequences for breaking it. At the end of the poem, when Beowulf is old and owns his own kingdom, he has to fight the dragon alone, since all his followers except Wiglaf break their oaths and run away. In the end, Beowulf is gravely injured and dies after killing the monster. Wiglaf rebukes the cowardly soldiers and reminds them of the consequences of abandoning one's lord:

So it is goodbye now to all you know and love on your home ground, the open-handedness, the giving of war-swords. Every one of you with freeholds of land, our whole nation, will be dispossessed, once princes from beyond get tidings of how you turned and fled and disgraced yourselves. A warrior will sooner die than live a life of shame (ibid. 195)

From such a perspective, it can be seen that as much as executing one's obligations to his lord brings order to the AngloSaxon heroic world, cowardliness and therefore failure to follow them brings disaster both to lord and warrior alike. While lords die or lose their kingdoms, warriors are stripped of their possessions and sentenced to exile. The last two lines can also be interpreted as suggesting that suicide is preferable to a dishonorable life.

Another integral part of the heroic code is the revenge obligation. One can see that even monsters in the Anglo-Saxon

6 | Celal Bayar Üniversitesi Sosyal Bilimler Dergisi - Cilt: 13, Sayı: 3, Eylül 2015 
imagination hold feuds, as Grendel's mother tries to avenge her dead son. However, taking revenge for someone's death or injury necessitates kinship or lordship ties with the harmed person in order to be legitimate. Thus, one cannot punish a stranger, which would then be regarded as murder. In "Beowulf, Byrhtnoth, and the Judgment of God: Trial by Combat in Anglo-Saxon England", Morton W. Bloomfield argues that Beowulf's first fight with Grendel in Hrothgar's mead-hall can be interpreted as a "trial by combat"2, and claims that Beowulf's victory is interpreted by Hrothgar as God's wisdom, and that the imagery of God pervades the whole fighting scene (Bloomfield, 1969: 546):

Neither the battle with Grendel's mother nor with the dragon is put so unequivocally in terms of God's power and judgment. In these two cases, Beowulf is directly concerned. His men have been killed, and he is carrying out the sacred duty of revenge. In the first combat, however, he is coming from the outside and justice may not be on his side. His legal and possibly moral position may not be firm; he needs above all to appeal to God. (ibid. 546)

Considering that it is unclear whether Grendel attacks Hrothgar's kingdom unprovoked or not in the poem, it is dubious whether Beowulf has the right to interfere with the events. Heroic code necessitates ties of either kinship or lordship in order to take revenge from someone. Beowulf has neither kinship nor lordship ties with Hrothgar at the time of Grendel's attacks on Heorot, and thus, killing Grendel needs justification. Therefore, the "Beowulf" poet introduces the trial by combat theme in order to endorse Beowulf's killing Grendel.

Apart from the revenge theme, the war-band mentality is an important part of the Germanic heroic code. This structure is described under the name of "comitatus" by the Roman historian Tacitus. Comitatus refers to the brotherly bond between the Germanic lord and his followers, which entails that neither side abandons the other in the battle. Tacitus describes this Germanic military organization and its spirit in his Germania thus:

When they go into battle, it is a disgrace for their chief to be surpassed in valor, a disgrace for his followers not to equal the valor of the chief. And it is an infamy and a reproach for life to have survived the chief, and

\footnotetext{
${ }^{2} \mathrm{~A}$ Germanic tradition where a physical duel is conducted in order to see who is right in the eyes of God (Bloomfield, 1986: 546).
} 
returned from the field. To defend, to protect him, to ascribe one's own brave deeds to his renown, is the height of loyalty. The chief fights for victory; his vassals fight for their chief. (Tacitus, 2010: 934)

Considering the brotherhood mentality among of the Germanic warriors, one can be puzzled in several scenes of "Beowulf". For instance, before Grendel's attack on the mead-hall, Beowulf hears the monster at the door, but he does not alert his sleeping soldiers. Also, in the first moments of Grendel's attack on Heorot, Beowulf leaves fighting to his followers and watches the monster kill one of his men in order to observe its manner of fighting:

[...] Mighty and canny,

Hygelac's kinsman was keenly watching

for the first move the monster would make.

Nor did the creature keep him waiting

but struck suddenly and started in;

he grabbed and mauled a man on his bench,

bit into his bone-lappings, bolted down his blood

and gorged on him in lumps, leaving the body

utterly lifeless, eaten up

hand and foot [...] (ibid. 49)

At first sight, the reader might be surprised by Beowulf's indifference to his companion's demise in this scene, in spite of the supposed brotherhood among the war-band. However, as Arthur K. Moore explains in "Beowulf's Dereliction in The Grendel Episode", as a leader, Beowulf is more interested in the general good of the kingdom, rather than a single soldier (Moore, 1953: 168). By observing the monster first, he learns its tactics and is able to drive it away quicker and with less effort, causing less harm for everyone in the long run:

He is in actuality the symbol of tribal security, solidarity, and continuity, and must therefore employ his powers as judiciously as possible. Accordingly, the poet's contemporaries perhaps regarded Beowulf's prudence as altogether proper rather than blameworthy (ibid. 168)

Since this article is concerned with elaborating on the differences between the earlier and later portrayal of heroic code in Anglo-Saxon poetry, it is also necessary to consider how "Beowulf" presents the lords to its audience. Therefore, it is necessary to point out how responsibilities of the kings are more frequently reminded to the reader in "Beowulf" than more recent works like "The Battle of Maldon", or "Exodus". The first and foremost of these responsibilities

8 | Celal Bayar Üniversitesi Sosyal Bilimler Dergisi - Cilt: 13, Sayı: 3, Eylül 2015 
is the practice of gift-giving. The heroic code necessitates gift-giving by the lord as a payment for the services of the warriors, and in "Beowulf" this occurs in countless scenes: "For his heroism / I will recompense (Beowulf) with a rich treasure (ibid. 27)"; "There's nothing you wish for / that won't be yours if you win through alive" (ibid. 45); "I will compensate (Beowulf) for settling the feud / as I did the last time with lavish wealth, / coffers of coiled gold, if you come back" (ibid. 97).

In fact, throughout "Beowulf", Beowulf receives many gifts from both Hrothgar and Hygelac, and it is typical of the poet to describe these treasures at length ${ }^{3}$. Through these lengthy descriptions, the poet highlights the kingly duty to the poem's audience, and by these exaggerated accounts of wealth distribution, he emphasizes Hrothgar's and Hygelac's generosity. For instance, after his death, Hrothgar is described as thus:

[...] Hrothgar's generosity

was praised repeatedly. He was a peerless king

until old age sapped his strength and did him

mortal harm, as it has done so many (ibid. 129)

In the poem both Hrothgar and Hygelac are thus characterised as "good" kings. Quite interestingly, when Hrothgar tells the tale of King Heromod, he claims that Heromod was not a good king because: "he grew bloodthirsty, gave no more rings / to honor the Danes. (ibid. 119)", and that "he covets and resents; dishonors custom / and bestows no gold" (ibid. 121). It is noteworthy that "a good king" in "Beowulf" is always either fearsome like Shield Sceafson (ibid. 11) or generous like Hrothgar (ibid. 59). Thus, one can see that dealing gold and other treasures to retainers is the prerequisite for one's reputation as a good king.

As I suggest that Beowulf presents a world where kings do not yet have absolute power over their retainers, it is also important to focus on the scenes where kings are shown dependent on their soldiers. As it is going to be pointed out later, later Anglo-Saxon poems like "The Battle of Maldon" portray warriors as dependent on their lords and not in the opposite way. These poems portray their authority figures in a manner which highlights masculinity and the idea of a strong leader. The "Beowulf" poet however, liberally employs scenes where weaknesses of kings are visible. Many scenes exist in the poem where the reader can see kings helpless, mournful, and emotionally weak. After Grendel's attacks, King Hrothgar is described as:

${ }^{3}$ One can see examples of these descriptions in lines 1019-61, and 2144-76. 
[...] stricken and helpless,

humiliated by the loss of his guard,

bewildered and stunned, staring aghast

at the demon's trail, in deep distress (ibid. 11)

Similarly, it is told that in the kingdom, instead of Hrothgar, "Grendel ruled in defiance of right (ibid. 11)", and "for twelve winters, seasons of woe / the lord of the Shieldings suffered under / his load of sorrow" (ibid. 11). Hrothgar is anxious and insecure when he talks about Grendel's mother as well:

He (Grendel) died in battle,

paid with his life; and now this powerful

other one arrives, this force for evil

driven to avenge her kinsman's death (ibid. 93)

Similarly, late in the poem, after Beowulf gets old and becomes a king himself, the narrative loses its former masculine and heroic quality at times, and a more reflective and sentimental mood intrudes the poem. In "King Hrethel's Sorrows and the Limits of Heroic Action in Beowulf" Linda Georgianna writes on the loss of the heroic atmosphere, which paints the whole Grendel episode:

Beowulf's fight with the dragon at times seems a thin, brief, somewhat dreamlike moment all but overwhelmed by the involved, repetitive accounts of past action and forecasts of the future: how the treasure came to be here, how the dragon came to be here, how Beowulf came to be here, and what will become of them all and the Geatish people with them. The heroic moment, the present, so significant at the poem's beginning, is in the second part almost bled of significance and reality as meaning shifts to the past and future. (Georgianna, 1987: 831)

Georgianna similarly defines Beowulf's last speech before his fight with the dragon as a:

retrospective, highly digressive, meditative speech, less a preamble to action than an amble through various related and unrelated memories of childhood, both joyful and sorrowful, memories of the brave deeds of kinsmen and finally of his own glories as a hero (ibid. 831)

which can also be interpreted as unheroic portrayal of "Beowulf" the king.

Another scene in "Beowulf" depicts a different king in a sentimental and emasculated way. As Beowulf nostalgically reflects upon his youth before attempting to kill the dragon, he remembers

10 | Celal Bayar Üniversitesi Sosyal Bilimler Dergisi - Cilt: 13, Sayı: 3, Eylül 2015 
King Hrethel, who looked after him as a child. Hrethel had two sons and one of them had killed the other, which could not be avenged because Hrethel would then have to kill his only remaining son. As a result of his grief over his dead son and shame for leaving his death unavenged, the king dies in the end. His sorrow is not dignified and kingly, and likened by the poet to the misery of an ordinary old man who watches helplessly as his son hangs on the gallows. Likewise, the tone of the poem in the rest of the scene is not heroic, and it closely resembles an Anglo-Saxon elegiac poem:

He gazes sorrowfully at his son's dwelling,

the banquet hall bereft of all delight,

the windswept hearthstone; the horsemen are sleeping,

the warriors under ground; what was is no more.

No tunes from the harp, no cheer raised in the yard.

Alone with his longing, he lies down on his bed

and sings a lament; everything seems too large,

the steadings and the fields. (ibid. 167)

With all these examples, one can see that the earlier AngloSaxon poets were not afraid to portray the lords as weak and to break their masculine aura.

Lastly, a speech in "Beowulf" is especially helpful in showing the authority warriors could have over their kings. After Grendel is killed by Beowulf, Hrothgar is troubled again when Grendel's mother attacks Heorot to avenge her son, and kills Eschere, one of Hrothgar's best retainers. Hrothgar hears the tales about this new monster and is further distressed that she will strike again. At that point, Beowulf steps up and reminds him of the proper heroic behavior, and asks him to "be a man":

Wise sir, do not grieve. It is always better

to avenge dear ones than to indulge in mourning.

For every one of us, living in this world

means waiting for our end. Let whoever can

win glory before death. When a warrior is gone,

that will be his best and only bulwark.

So arise, my lord, and let us immediately

set forth on the trail of this troll-dam.

I guarantee you: she will not get away, not to dens under ground nor upland groves

nor the ocean floor. She'll have nowhere to flee to.

Endure your troubles to-day. Bear up and be the man I expect you to be (ibid. 97)

One can see here that although Hrothgar is socially superior to Beowulf, he is portrayed by the poet in a distressed manner and 
Beowulf's comments above can be considered as reproachful. In fact, all scenes highlighted so far sufficiently exemplify the assertion that "Beowulf" presents a less strict version of the heroic code for the retainers. The responsibilities of the lords are highlighted in the poem as equally as the responsibilities of retainers, and as seen in the last two examples, the poet does not hesitate to use weakened, unheroic, and emasculated portrayals of Beowulf the king, Hrethel, and Hrothgar.

IV. "The Battle of Maldon"

"The Battle of Maldon" on the other hand, is a late AngloSaxon poem commemorating the Anglo-Saxon defeat at Maldon, Essex in 991 against a Danish army. Although considerably shorter than many other Anglo-Saxon poems, "The Battle of Maldon" is much more compact and unified. Therefore it is much easier to observe the military values and interpret the heroic principles in "Maldon". Unlike "Beowulf", its subject matter is not fictional, but historical, and it is possible to find the names of the protagonist and the location of the battle in the Anglo-Saxon Chronicle. The entry in the Anglo-Saxon Chronicle for the year 991 reads:

This year was Ipswich plundered; and very soon afterwards was Alderman Britnoth slain at Maldon. In this same year it was resolved that tribute should be given, for the first time, to the Danes, for the great terror they occasioned by the sea-coast. That was first 10,000 pounds. (The Anglo-Saxon Chronicles, 2000: 91)

The poem speaks about one of the many Danish attacks on England. According to the poem, the English army commanded by Earl Byrhtnoth and the Danish army meet close to modern day Blackwater River. However, the Danish army is stranded on a small island on the river, and the battle cannot start. So, the Danish army asks to be allowed onto the battlefield in order to have a fair fight. Byrhtnoth complies with their request, allows the Danish army to pass the causeway, and the fighting begins. The fight concludes with the defeat of the Anglo-Saxons, and the death of Byrhtnoth with his companions, but since the manuscript is damaged, the conclusion of the poem is lost.

Comparing the two poems allows us to see that while "Beowulf" presents an earlier, less strict version of the heroic code, the heroic code in "The Battle of Maldon" is static and rigid. In "Beowulf", the responsibilities of the warriors and the responsibilities of the kings are shown as equally important, and receive similar treatments by the poet. For each scene the reader is reminded of the duties of warriors in "Beowulf", there are enough

12 | Celal Bayar Üniversitesi Sosyal Bilimler Dergisi - Cilt: 13, Sayı: 3, Eylül 2015 
parts to balance them with the responsibilities of the kings as well. However, in "The Battle of Maldon" -a much later work- a sense of military obedience can be felt at the background all the time, and the poem almost exclusively speaks about the military obligations of warriors. Besides, "The Battle of Maldon" glorifies suicidal loyalty in a much denser way than found in any other Anglo-Saxon poem. Thus, one can see that there is a difference in the representation of the heroic code between earlier and later works of Anglo-Saxon literature.

One of the most interesting and probably the most discussed question about "The Battle of Maldon" is probably about Byrhtnoth's decision to allow the Vikings a safe passage onto the mainland, and losing the territorial advantage he has:

When they realized that and clearly perceived

that they had encountered there fierce guardians of the causeway,

the hostile strangers then began to become guileful, asked that they might have passage onto land, go over the ford, lead their troop.

Then the earl, on account of his overconfidence began to give too much ground to the hostile people (ibid. 8)

As well as stemming from his overconfidence, Byrhtnoth's refusal to make peace through gold can also be rooted in a sense of patriotism as well. Therefore, it is perfectly plausible that he is conscious of a proto-nationalist ideal. Byrhtnoth knows that by paying ransom to the Danes and allowing them to leave unharmed, he would be sending them off to a different part of England, where they would harm and raid other fellow Anglo-Saxons. Although we cannot talk about the concept of nationalism during Anglo-Saxon Era, the idea of a common destiny and purpose for the English people is not unthinkable. In this sense, in "Anglo-Saxon Society and its Literature" Patrick Wormald writes on the patriotism in two late Anglo-Saxon poems, "The Battle of Maldon", and "Battle of Brunanburh" that:

The kingdom of England did not fuse spontaneously; it had to be welded by the mixture of force, cajolery and propaganda that is the stuff of statecraft in any age. Nonetheless, the English kingdom was a reality by the eleventh century. There is evidence that speakers of what we call Old English were willing to call themselves 'English'. The two heroic poems that certainly were written after 900, on the Battles of Brunanburh and Maldon, express precisely the note of authentic 
'patriotism' that is absent in the others. (Wormald, 2002: 14-15)

The primary difference to be emphasized between "The Battle of Maldon" and earlier poems like "Beowulf" is their portrayal of military authority. While Beowulf is primarily an independent warrior, Byrhtnoth is a soldier and more specifically a commander of a king's army. Beowulf also has his social superiors and subordinates; yet, the poet depicts him mainly as a solitary character. Byrhtnoth however cannot exist in a world without a king or an army to be a part of. As Ralph W. V. Elliott writes in his "Byrhtnoth and Hildebrand: A Study in Heroic Technique":

Everything in "The Battle of Maldon" -every speech, every action, every allusion- is directed to the illustration of the central theme of military obedience. In fact, while both protagonists display courage, it is the ever present sense of leadership and discipline that sets Byrhtnoth apart from Beowulf (Elliott, 1962: 56)

Apart from their thematic differences, the stylistic differences between "Beowulf" and "The Battle of Maldon" also make the shift in the heroic code apparent. Firstly, "Beowulf" has faults with respect to its unity, and the poet contradicts himself on different scenes, or overlooks previous details. "The Battle of Maldon" on the other hand, is quite short and therefore relatively free of such flaws. The two poems also differ heavily in their vocabulary, style, and mood. Elliott claims:

That the phraseology of Maldon is thoroughly conventional is the natural result of the rejection of the grand style. The paucity of kennings, the absence of ornament, the preference of simple words over compounds, all indicate a poet who was deliberately departing from the more elaborate stylistic tradition in favor of the plain style. (ibid. 60-61)

Thus, one may see that "Maldon" is a conscious product of its composer, complete with its own ideology, introducing God or Christianity only when necessary and at precisely the right moment, while "Beowulf" is similar to a folk-tale, using Christian and heroic elements randomly and contradictorily. The marriage of paganism and Christianity in "Beowulf" is not to educate, but to entertain and appeal to its audience, whereas the "Maldon" poet combines them carefully in order to give a warning, to instill obedience to the king, and to set an example for its audience.

14 | Celal Bayar Üniversitesi Sosyal Bilimler Dergisi - Cilt: 13, Sayı: 3, Eylül 2015 


\section{Anglo-Saxon Translation of "Exodus"}

Another text which can be compared with "Beowulf" and "The Battle of Maldon" is the Anglo-Saxon translation of the Biblical Exodus story. "Exodus" presents an interesting case, since The Old English version of the biblical "Exodus" narrative is not simply a translation from Latin but a paraphrase in heroic style. Specifically, it is an account of the Israelites being led out of slavery in Egypt by Moses. After they are released, the Pharaoh decides to reclaim the slaves he loses, and begins tracking them with his army. After Moses parts the Red Sea and the Pharaoh and his armies are drowned, the chase is over, and the Israelites are finally saved by Moses who leads them into safety. However, the similarity between the biblical and the Anglo-Saxon Exodus ends here. While the two poems are similar with respect to their plots, they are completely different in their styles. That is, the Old English "Exodus" is written in a way which follows the conventions of the heroic style of Anglo-Saxon poetry. Moses is described as a commander, and during the final battle scene between the Israelites and Moses, Old English formulaic devices such as the beasts of battle ${ }^{4}$ are used. In general, a military imagery and tone pervades the poem.

The similarity of "Exodus" and the heroic poems is perceivable even in the first lines, as Old-English "Exodus" opens remarkably similar to Beowulf. The poem starts by recounting Moses' services to God in a heroic style:

Lo! Far and wide throughout the earth we have heard how the laws of Moses, a wondrous code, proclaim to men reward of heavenly life for all the blessed after death, and lasting gain for every living soul. Let him hear who will! ("Exodus", 2000: 2)

Similarly, "Beowulf" starts by recounting Scyld Scefing's heroic actions:

So. The Spear-Danes in days gone by

And the kings who ruled them had courage and greatness.

We have heard of those princes' heroic campaigns.

There was Shield Sheafson, scourge of many tribes,

A wrecker of mead-benches, rampaging among foes (ibid. 3)

4 "Beasts of battle" is a literary device which employs the imagery of the three animals that Old English and Old Norse societies associated with war: the wolf, the raven, and the eagle. These animals appear during the battle scenes in the AngloSaxon poems "Battle of Brunanburh", "The Battle of Maldon", "Beowulf", "Elene", "Exodus", "The Fight at Finnsburgh", "Genesis A", "Judith", "The Wanderer", and the Old Norse "Poetic Edda". 
The choice of the "Exodus" poet to address the reader in such a style in a religious poem is interesting, since both "Beowulf" and "Exodus" poems try to appeal to the audience in the same manner, by recounting heroic deeds of their characters, despite the fact that they were composed centuries apart.

Apart from these, throughout "Exodus", Moses is treated more like a Germanic war-chief, than a prophet. He is no doubt a religious figure in the poem, yet his actions and words echo those that can be seen in "Beowulf", or "The Battle of Maldon". He is frequently called in the poem as: "prince of the people", "wise guide of the host", "bold leader", "a prince unafraid", "glorious hero", and "the king". These details contribute to the culturally syncretic nature of "Exodus", coloring a biblical story with heroic details. The "Exodus" poet describes Moses as:

He was beloved of God, a lord of men, a wise and ready leader of the host, a bold folk captain. Affliction came upon the tribe of Pharaoh, the enemy of God, when the Lord of victories entrusted to the bold folk-leader his kinsmen's lives, and gave the sons of Abraham a dwelling and a habitation. Great was his reward! The Lord was gracious unto him and gave him weaponmight against the terror of his foes, wherewith he overcame in battle many a warrior, and the strength of hostile men. (ibid. 2)

In Anglo-Saxon poetry, the longing for a lord, the loss of one's honor and having to live a life of shame are some of the recurring themes, and these aspects are all related to losing the king's favor. Outliving one's own lord leads to a life of exile and the loss of a meadhall, where warriors bound to a certain lord are sheltered, fed, and entertained. In this sense, religious content presented in heroic style can be encountered at the beginning of "Exodus", where the Pharaoh's defeat is described by the poet as:

Mourning was renewed at the fall of their keepers of treasure; joys in hall passed away with the loss of possessions; at midnight He had boldly struck down the evil-doers; many first-born children had slain the watchmen; the destroyer stalked far and wide, the hated foe of the people; dark grew the land with bodies of the slain. There was lamenting far and wide, little rejoicing. (ibid, 112)

It is obvious here that the scribe of "Exodus" still bears the imagery of the mead-hall in mind. Expressions like "keepers of treasure", "joys in hall", "loss of possessions", and "lamenting far and

16 | Celal Bayar Üniversitesi Sosyal Bilimler Dergisi - Cilt: 13, Sayı: 3, Eylül 2015 
wide" all point out to the mead-hall, which is already a memory of the past at the time of "Exodus" translation. One can easily see here that the poet equals the loss of God's favor with the loss of king's favor.

The Anglo-Saxon version of Exodus is also interesting in the different ways it contributes to the formation Alfred's vision of the heroic code. King Alfred begins his legal code with a long excerpt from "Exodus", describing Moses spreading his laws and he thus presents himself in a tradition of law-givers which begins with Moses. This shows how religion and religious poetry were instrumental in the hands of late Anglo-Saxon rulers. Aside from assuming a "law-giver" image for himself, by beginning his own law code with "Exodus", Alfred imitates Moses' image as the leader of a suffering nation. In this sense, one should remember that Alfred resisted the Danish invasions and eventually repelled their attacks and reacquired much of the English territory invaded by the Danes. Thus, the portrait of Alfred created in Anglo-Saxon "Exodus" is similar to that of Moses, who saves his people from a stronger and pagan enemy, and leads his people to the Promised Land.

\section{The Anglo-Saxon Chronicle}

In this respect, another text that can be addressed is The Anglo Saxon Chronicle which is a chronological account of the events in England during Anglo-Saxon and Norman rules. It is a compilation of seven surviving interrelated manuscripts which are primary sources for the early history of England. The chronicle was first assembled by the orders of King Alfred but narrates the history of Anglo-Saxons, starting from their arrival to Britain, and was carried on after Alfred's death as well.

Comparing The Anglo-Saxon Chronicle with other contemporary historical documents reveals that it omits or tells partial accounts of certain events. For instance, The Anglo-Saxon Chronicle recounts the coming of the Anglo-Saxons to England as the arrival of small fleets to different parts of England. The way The Anglo-Saxon Chronicle handles the arrival of the Anglo-Saxons is in fact, misleading, and the chronicle employs a propagandistic approach on the events, rather than a historical one. The impossibly small number of ships given in the Chronicle for the invasion of Britain such as: "three ships of Hengest and Horsa; three ships of Ella; five ships of Cerdic and Cynric; three ships of Stuf and Wihtgar", hurts the Chronicle's credibility as a historical source and is probably drawn from the Anglo-Saxon poetic tradition of understating a hero's material means against a more powerful enemy. The inaccurate and anachronistic place names mentioned in the Anglo-Saxon Chronicle also further hurt its credibility. The fact that the scribe of The Anglo- 
Saxon Chronicle says Earl Cerdic arrived at Cerdic's Shore, and Earl Port arrived at Portsmouth points out to a culturally biased viewpoint which also favors King Alfred's vision of "Ængla-land" as the land of the English people.

\section{Conclusion}

It is thus possible to see the practical utilization of the heroic code in "The Battle of Maldon", "Exodus", and "The Anglo-Saxon Chronicle". It can be seen in these texts that the scribes' perceptions of the heroic code are more rigid when compared to the representation of the same ideals in "Beowulf". While "Beowulf" presents hierarchical but less restrictive relations between the warriors and the rulers, the poet of "The Battle of Maldon" consciously intends to strengthen the limitations against the soldiers in favor of their lords. Commander Byrhtnoth refuses to pay ransom to the Danes and to send them elsewhere, since this would mean sending them away to raid some other part of 'England'. In its composer's worldview, kingdoms of Wessex, Mercia, or Northumbria do not exist anymore, and Byrhtnoth must defend the whole of England. While earlier poems like "Beowulf" present less restrictive relations between retainers and warlords, the poet of "The Battle of Maldon" strengthens the limitations against retainers in favor of their lords. That is to say, "The Battle of Maldon" constantly reminds the duties of the retainers and never mentions a single kingly responsibility. Similarly, Anglo-Saxon translation of "Exodus" presents Moses as a king rather than a prophet, and there is a striking similarity between the way Moses' story and Alfred's war efforts are presented. King Alfred's law codes begin with an excerpt from "Exodus" which compares Alfred's struggle against the Danes to that of Moses against the Pharaoh. Similarly, in Alfred's translation of "Exodus" into Old English, Moses is a "prince of the people", "wise guide of the host", "bold leader", a "prince unafraid", and a "glorious hero". That is to say, he is more of a Germanic king than a prophet. Lastly, "The Anglo-Saxon Chronicle" is more inclined to foster an English identity by making up anachronistic place names, named after their Anglo-Saxon conquerors. Moreover, simply by commissioning "The Anglo-Saxon Chronicle", Alfred suggests continuity between the earlier chieftains of the Anglo-Saxon tribes and himself as the king of England and the English people. Thus, it is possible to see the way late Anglo-Saxon literature make use of the heroic code in order to foster dependence on a single king, instead of former tribal loyalties.

Through the survey of the Anglo-Saxon history and politics presented in this article, one can see the changes in the political

18 | Celal Bayar Üniversitesi Sosyal Bilimler Dergisi - Cilt: 13, Sayı: 3, Eylül 2015 
condition of England during the $9^{\text {th }}$ and $10^{\text {th }}$ centuries. Prior to the Danish attacks on England, several Anglo-Saxon kings reigned together, and this led to animosity, rivalry and a lack of a common 'English' identity between the kingdoms. It is therefore possible to conclude that the changes in the political condition of England led to changes in the interpretation of identity as well. The existence of multiple kings led to infighting between the Anglo-Saxons. However, the emergence of Wessex as the only English kingdom after the Danish invasions allowed the Anglo-Saxon ruling class to centralize their authority and to create an 'English' identity, while using literature in order to alter the heroic code according to their own needs.

\section{WORKS CITED}

BEOWULF: A New Verse Translation. (2000). (S. Heaney, Trans.) New York: Norton\&Company.

BLOOMFIELD, M. W. (1969, October). Beowulf, Byrhtnoth, and the Judgment of God: Trial by Combat in Anglo-Saxon England. Speculum, 44(4), pp. 545-559.

ELLIOTT, R. W. (1962, Winter). Byrhtnoth and Hildebrand: A Study in Heroic Technique. Comparative Literature: Studies in Old English Literature in Honor of Arthur G. Brodeur, 14(1), pp. 53-70.

EXODUS. (2000). (E-Book). (C. W. Kennedy, Trans.) Ontario. Retrieved from http://www.yorku.ca/inpar/Exodus_Kennedy.pdf

FISHER, D. J. (1973). The Anglo-Saxon Age. Aberdeen: Aberdeen UP.

GEORGIANNA, L. (1987, October). King Hrethel's Sorrow and the Limits of Heroic Action. Speculum, 62(4), pp. 829-850. Florida UP.

HILL, J. M. (2000). The Anglo-Saxon Warrior Ethic. Florida:

LANCASTER, L. (1958, December). Kinship in Anglo-Saxon Society: II. The British Journal of Sociology, 9(4), pp. 359-377.

MOORE, A. K. (1953, March). Beowulf's Dereliction in the Grendel Episode. Modern Language Notes, 68(3), pp. 165-69.

O'KEEFFE, K. O. (2002). Heroic Values and Christian Ethics. In M. Godden, \& M. Lapidge, The Cambridge Companion to Old English Literature (pp. 107-125). Cambridge: Cambridge UP.

TACITUS. (2010). Germania (Kindle Edition). (C. River, Ed.) Amazon Digital Services.

The Anglo-Saxon Chronicles. (2000). London: Phoneix Press.

The Battle of Maldon. (1970). In Old English Grammar and Reader (R. E. Diamond, Trans.). Detroit: Wayne State University. 
Safak Nediceyuva

WORMALD, P. (2002). Anglo-Saxon Society and its Literatue.

In The Cambridge Companion to Old English Literature (pp. 1-22). Cambridge: Cambridge UP. 